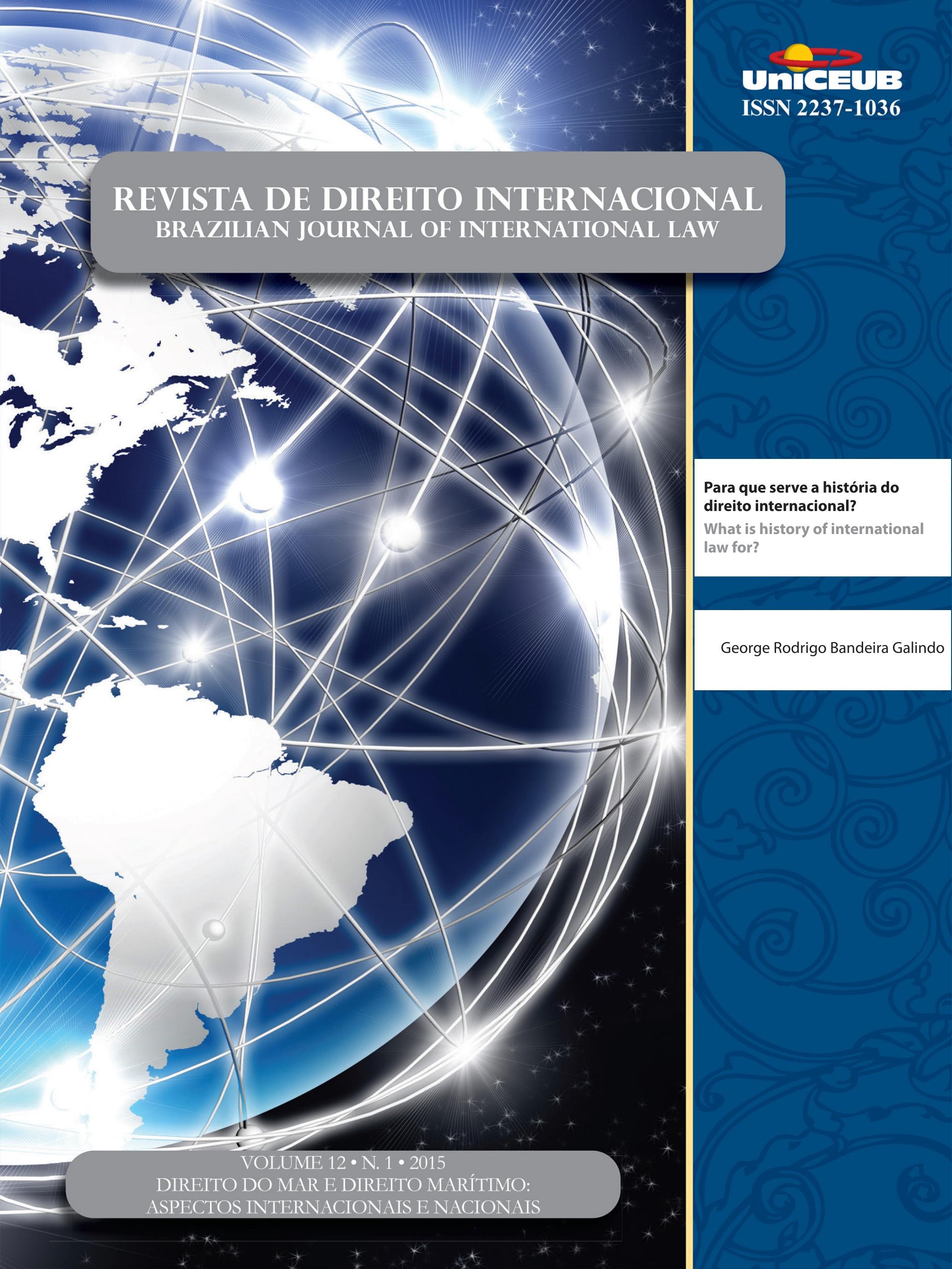




\section{Sumário}

\section{Crônicas}

CRôNICAS DA ATUALIDADE do DiREITO INTERNACIONAL ........................................................ 2

Nitish Monebhurrun (org.)

Towards a european regulation of the importation of conflict minerals?..... 2

Nitish Monebhurrun

Keeping up with the terrorists: the EU's proposed Passenger Name Records (PNR) Directive \& european security

Eshan Dauhoo

A histórica reaproximação de Cuba e EUA

Erika Braga

A contextualização da atual reivindicação da Grécia para receber indenizações por atos da Alemanha durante a Segunda Guerra Mundial . .10

Natália da Silva Gonçalves

José Eduardo Paiva Miranda de Siqueira

Crônicas da jurisprudência do Direito Internacional (CIJ/ITLOS): Decisões da Corte Internacional de Justiça e do Tribunal Internacional Sobre o Direito do Mar .14

Nitish Monebhurrun (Org.)

Corte Internacional de Justiça

Estudo da decisão da Corte Internacional de Justiça no caso Croácia v. Servia (03/02/2015) .14

Liziane Paixão Silva Oliveira e Maria Edelvacy Marinho

Questões relacionadas com a apreensão e detenção de certos documentos e dados: (Timor Leste c. Austrália) - O reconhecimento do retorno de uma relação amigável entre Timor-Leste e Austrália e a nova decisão da CIJ, 6 de maio de 2015 . 20

Gleisse Ribeiro Alves

Tribunal Internacional sobre Direito do Mar

Caso da delimitação da fronteira marítima entre o Gana e a Costa do Marfim no Oceano Atlântico: medidas cautelares $(25 / 04 / 2015)$

Nitish Monebhurrun

Comentário à Opinião Consultiva 21 do Tribunal Internacional para o Direito Do Mar [02/04/2015] (Responsabilidade do Estado de Bandeira pela pesca ilícita, não declarada ou não regulamentada) ...............25

Carina Costa de Oliveira 
CRÔNICAS DO DIREITO INTERNACIONAL DOS INVESTIMENTOS

Nitish Monebhurrun (Org.)

A inclusão da responsabilidade social das empresas nos novos Acordos de Cooperação e de Facilitação dos Investimentos do Brasil: uma revolução 33

Nitish Monebhurrun

\section{O Direito do Mar Perante as JuRisdições INTERnacionais}

CoAstal States' Rights IN THE MARITIME AREAS UNDER UNCLOS .40 Tullio Treves

TACKling illegal, unregulated And unReported Fishing: THE ITLOS Advisory OpINION on Flag State Responsibility for IUU fishing AND THE PRINCiple of DUE DiligenCE ...50 Victor Alencar Mayer Feitosa Ventura

REFLEXões PROVENIENTES do DisSENSO: UMA ANÁLISE CRÍtica A RESPEITO do CASO Austrália versus Japão Perante a Corte InTERnacional de JustiçA .......................................68 Luciana Ferna ndes Coelho

Os TRATADOS INTERNACIONAIS DE DIREITO DO MAR E SEUS EFEITOS SOBRE TERCEIROS ESTADOS ..... 86 Tiago V. Zanella

\section{InStRumentos JURÍdicos PARA A GeStÃo do MAR}

OS LIMITES DOS TERMOS BEM PÚBLICO MUNDIAL, PATRIMÔNIO COMUM DA HUMANIDADE E BENS COMUNS PARA DELIMITAR AS OBRIGAÇÕES DE PRESERVAÇÃO DOS RECURSOS MARINHOS 109 Carina Costa de Oliveira e Sandrine Maljean-Dubois

Os limites do PLANEJAMENTO DA OCUPAÇÃo SUSTENTÁVEL DA ZONA COSTEIRA BRASILEIRA ... 126 Carina Costa de Oliveira e Luciana Coelho

CORRENDO PARA O MAR NO ANTROPOCENO: A COMPLEXIDADE DA GOVERNANÇA DOS OCEANOS E A ESTRATÉGIA BRASILEIRA DE GESTÃO DOS RECURSOS MARINHOS 
A comissão de limites da Plataforma continental (CLPC) E Os DESAFios Na delineaÇÃo DAS PLATAFORMAS CONTINENTAIS ESTENDIDAS................................................... 170

Alexandre Pereira da Silva

\section{A PROTEÇÃo DO MEIO AMBIENTE MARINHO}

O gRANDE JOGo do ÁrTiCo: REFLEXões COM BASE NA PERSPECTIVA DE EXPLORAÇão ECONÔMICA

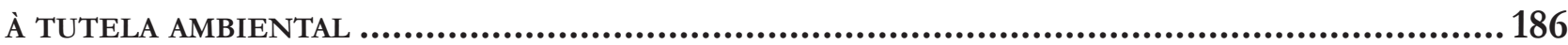

Fernando Rei e Valeria Cristina Farias

Instrumentos Públicos e Privados para a reparação do dano ambiental causado por DERRAMAMENTO DE ÓLEO NO MAR SEM ORIGEM DEFINIDA: AS MANCHAS ÓRFÃS

Renata Brockelt Giacomitti e Katya R. Isaguirre-Torres

O DIREITO INTERNACIONAL PRIVADO E A RESPONSABILIDADE CIVIL EXTRACONTRATUAL POR DANOS AMBIENTAIS CAUSADOS POR TRANSPORTES MARÍTIMOS À LUZ DO DIREITO BRASILEIRO ....... 217 Inez Lopes

A NECESSIDADE DE REPENSAR OS MECANISMOS DE RESPONSABILIDADE AMBIENTAL EM CASO DE riscos de VAZamento de PETRóleo Na Zona Econômica Exclusiva do BrasiL

Marcelo D. Varella

\section{Problemáticas do Direito Marítimo}

A FisCALIZAÇão SANitÁRIA DAS EMBARCAÇÕES EM ÁGUAS JURISDICIONAIS BRASILEIRAS: NOTAS aCERCA da (IN)efetividade da Súmula 50 da AGU

Joedson de Souza Delgado e Ana Paula Henriques da Silva

A IMO E A REPRESSÃo AO ROUBO ARMADO CONTRA NAVIOS: DA RETÓRICA INTERNACIONAL À COOPERAÇÃO REGIONAL

André Panno Beirão e Charles Pacheco Piñon

\section{O Direito do Mar diante da Pirataria}

O DIREITO INTERNACIONAL EM FACE DA PIRATARIA EM ALTO-MAR: UMA PERSPECTIVA CRÍTICA.289 Maiquel Ângelo Dezordi Wermuth e Rafaela Correa 
Pirataria marítima: A EXPERIÊnCIA Somália

Eduardo Augusto S. da C. Schneider

\section{Temas Gerais}

DRAWING THE LINE: ADDRESSING ALLEGATIONS OF UNCLEAN HANDS IN INVESTMENT ARBITRATION*

Mariano de Alba

Para Que Serve a história do Direito internacional?

George Rodrigo Bandeira Galindo

As interferências entre a Política Externa e de Segurança Comum Europeia (Pesc) e O DiREITO DAS NaÇões UNIDAS

Leonardo de Camargo Subtil

Introdução Às regras de aplicaÇão da Convenção da ONU Sobre Contratos de ComPRA E VENDA INTERNACIONAL DE MERCADORIAS E O DIREITO INTERNACIONAL PRIVADO BRASI-

LEIRO 380

Paul Hugo Weberbauer e Eugênia Cristina Nilsen Ribeiro Barza

A REgulaÇÃo das EMPRESAS TRANSNACIONAIS ENTRE AS ORDENS JURÍDICAS ESTATAIS E NÃO ESTATAIS.

Mateus de Oliveira Fornasier e Luciano Vaz Ferreira

OUtLAWING HATE SPEECH IN DEMOCRATIC STATES: THE CASE AGAINST THE INHERENT LimitAtions doctrine concerning Article 10 (1) of the European Convention on Human

Rights 416

Stefan Kirchner 


\title{
Para que serve a história do direito internacional?*
}

\section{What is history of international law for?}

\author{
George Rodrigo Bandeira Galindo**
}

\section{Resumo}

Nas últimas décadas, a história do direito internacional tem se tornado importante campo de estudos no direito internacional. Por essa razão, a questão "para que serve a história do direito internacional?" é de grande importância. Este artigo objetiva respondê-la em duas etapas. Primeiro, é essencial reconhecer que a história do direito é inescapavelmente ligada à prática do direito de maneira que nenhum internacionalista é capaz de negar. Segundo, deve-se determinar que tipo de prática importa para a história do direito e tomar partido nesse tema. Tradicionalmente, internacionalistas fazem uso da história para manter o direito internacional ligado a suas origens ou para promover a sua evolução. Recentemente, contudo, alguns estudiosos estão fazendo uso da história do direito internacional para destruir ou questionar elementos do passado de maneira crítica. Essas são as atitudes estática, dinâmica e critica dos juristas em relação à história do direito. Para o autor, a atitude crítica em relação à história do direito internacional é mais capaz de permitir à disciplina cumprir valores como justiça. $\mathrm{O}$ desafio de construir histórias críticas do direito internacional envolve a ideia de que uma relação mais vigorosa entre história e teoria deve ser avançada. Ele também requer do internacionalista uma consciência ética sobre a situação atual do direito internacional. Ao final do artigo, é proposta uma resposta tentativa à questão posta no título no sentido de reconhecer que a história do direito (internacional) possui dimensão prática na qual a crítica cumpre papel fundamental.

Palavras-chave: História do direito internacional. Prática. Teoria do direito internacional. Ética.

* Recebido em: 01/05/2015 Aprovado em: 21/05/2015

** Professor e Diretor da Faculdade de Direito da UnB. Esta é a versão em português, revisada e ampliada, de GALINDO, George R. B. ¿Para qué estudiar la historia del derecho internacional? In: URUEÑA, René (Ed.). Derecho internacional: poder y límites del derecho en la sociedad global. Bogotá: Universidad de los Andes, Facultad de Derecho, Ediciones Uniandes, 2014. p. 3-25. Gostaria de agradecer a Guilherme Del Negro e aos revisores anônimos pela leitura atenta e comentários a este artigo. E-mail: ggalindo@unb.br.

\section{Abstract}

In the last decades, the history of international has become an important field of study in international law. Due to that, the question "what is the history of international law for?" is of utmost importance. This article aims to answer it in two steps. First, it is essential to recognize that legal history is inescapably attached to the practice of law in a way that no international lawyer can deny. Second, one must narrow down what kind of practice matters for legal history and take sides on such issue. Traditionally, international lawyers make use of history to keep international law rooted to its origins or to foster its evolution. Recently, however, some scholars are making use of 
history of international law to destroy or question elements of the past in a critical way. These are the static, the dynamic and the critical attitudes of lawyers vis-à-vis legal history. For the author, the critical attitude towards the history of international law is more capable to allow the discipline to fulfill values such as justice. The challenge of making critical histories of international law involves the idea that a more vigorous relationship between history and theory must be advanced. It also demands from international lawyers an ethical consciousness about the current situation of international law. At the end of the article, a tentative answer is advanced to the question posed on the title, one that recognizes that (international) legal history has a practical dimension in which critique plays a fundamental role

Keywords: History of International Law. Practice. Theory of International Law. Ethics.

\section{INTRODUÇÃO}

Alguns anos após o fim da Guerra Fria, Thomas Franck, um dos jusinternacionalistas americanos mais influentes do século XX, afirmou que o direito internacional entrara em uma "era pós-ontológica". A antiga questão de saber se "o direito internacional é direito" perdera sua centralidade. Os novos tempos apresentavam novos desafios e outras questões se tornavam mais prementes de serem respondidas, como: o direito internacional é efetivo? É aplicável? É compreendido? E, mais importante, ele é justo? ${ }^{1}$

Se a natureza jurídica do direito internacional não mais necessita ser explicada, o seu propósito, as suas funções precisariam? E quanto à história do direito internacional? Seria antiquado indagar sobre os seus propósitos e funções ou, simplesmente, para que ela existe ou serve?

Do mesmo modo que a pergunta "o direito internacional é direito?" ainda incomoda os juristas, ${ }^{2}$ perguntas sobre a utilidade da história do direito internacional, especialmente nos dias de hoje, igualmente incomodam muitos.

1 FRANCK, Thomas M. Fairness in international law and institutions. Oxford: Oxford University Press, 1998. p. 3-6.

2 Ver, por exemplo, HATHAWAY, Oona; SHAPIRO, Scott J. Outcasting: enforcement in domestic and international law. Yale Law Journal, New Haven, v. 121, n. 2, p. 252-349, 2011.
As respostas sobre o assunto têm variado. Alguns autores acreditam que o entusiasmo atual para com a história do direito internacional tem a ver com um senso de otimismo surgido após o fim da Guerra Fria: a possibilidade de manter um projeto liberal no direito internacional ou inaugurar uma ordem internacional completamente diferente. ${ }^{3}$ Outros associam o ressurgimento da história do direito internacional a um senso de ansiedade surgido após o fim da Guerra Fria: a fim de se orientarem em um ambiente internacional agora bastante diferente, os juristas precisam olhar para o passado em busca de respostas. ${ }^{4}$

"Para que serve a história do direito internacional?". A resposta à pergunta somente pode ser encontrada por etapas. A primeira diz respeito a entender se o jurista e o historiador encaram a história da mesma maneira. Este artigo parte do pressuposto de que não, em virtude de a história do direito (internacional) possuir viés prático candente. A constatação desse viés por si só, no entanto, não se mostra suficiente, uma vez que a dimensão prática pode servir a diferentes fins, que abaixo designo, com apoio de Robert Gordon, como: estático, dinâmico e crítico. A escolha por uma dessas três posturas já se constitui a resposta à segunda etapa antes mencionada. Pelas razões que exporei mais detalhadamente no correr do artigo, a adoção da atitude crítica é, nos dias de hoje, a que considero mais adequada para responder à pergunta do título.

Em resumo, o objetivo deste artigo consiste em responder à indagação "Para que serve a história do direito internacional?" Isso passa necessariamente por entender o caráter prático da história do direito internacional, em um primeiro momento, e porque a atitude crítica e suas implicações — são mais adequadas para o estado atual da história do direito internacional.

Nesse sentido, na primeira parte do artigo, demonstrarei que a história do direito em geral (e a história do direito internacional também) possui uma perspectiva prática inescapável. A história jurídica consiste em uma prática com as possíveis consequências, boas ou más, que isso traz. $\mathrm{Na}$ segunda parte, defenderei que essa prática precisa ser crítica se o direito busca ser um ins-

3 KOSKENNIEMI, Martti. Why history of international law today? Rechtsgeschichte, Frankfurt, v. 4, p. 61-66, 2004.

4 LESAFFER, Randall. International law and its history: the story of an unrequited love. In: CRAVEN, Matthew; FITZMAURICE, Malgosia; VOGIATZI, Maria (Ed.). Time, history and international law. Leiden: Martinus Nijhoff, 2007. p. 27-42. p. 3-5. 
trumento de mudança social, especialmente em favor daqueles que sofrem injustiças na ordem jurídica internacional contemporânea. Em seguida, sustentarei que o projeto crítico da história do direito internacional deve ser radicalizado tomando-se por base duas perspectivas: a necessidade de maior diálogo entre história e teoria e a percepção de que a história do direito internacional está intimamente ligada a aspectos éticos que afetam o mundo atual. Nas conclusões, tentarei responder à pergunta do título deste artigo com base em uma perspectiva histórica crítica do direito internacional.

\section{HISTÓRIA COMO PRÁTICA}

O passado cerca o presente do direito internacional de diferentes maneiras. Tomemos alguns exemplos.

É incomum encontrar algum manual de Direito Internacional Público que não se dedique, logo em suas primeiras páginas, a fazer um histórico de como os Estados estabeleceram um direito para regular as suas relações. Referências à paz de Westphalia, ao Descobrimento das Américas, à divisão entre católicos e protestantes são uma constante no imaginário histórico que o estudante iniciante de direito internacional deve desenvolver para bem compreender a disciplina.

Mas não somente os neófitos na disciplina precisam dominar o mínimo sobre a história do direito internacional. Tribunais internacionais utilizam a argumentação histórica constantemente. Para citar apenas um exemplo: em um de seus casos contenciosos mais célebres julgados nos últimos anos, Imunidades Jurisdicionais do Estado (Alemanha vs. Itália), a Corte Internacional de Justiça fez questão de incluir no princípio da sentença uma seção denominada: "Antecedentes históricos e factuais". Advogados especializados em direito internacional, funcionários de Ministérios das Relações Exteriores e mesmo juízes internos também fazem uso constante da argumentação histórica.

O uso da história é tão disseminado entre aqueles que praticam o direito internacional que muitos excessos acontecem no manejo das provas históricas para a construção de argumento jurídico. Aquilo que é comumente chamado nos Estados Unidos de "law office history" (história de escritório de advocacia) também se repete no direito internacional: a falta de rigor analítico na pesquisa histórica, o uso seletivo de materiais histó- ricos, o instrumentalismo explícito ou implícito na seleção de dados históricos e nas conclusões que se retiram desses materiais, a falta de desejo ou inabilidade para reconciliar fontes conflitantes ou mesmo a inabilidade para aceitar a ambiguidade e a incompletude dos dados históricos. $^{5}$

Diante disso, uma questão surge: por que os juristas práticos ou teóricos do direito internacional não abrem mão da história para construir seus argumentos?

Um dos mais importantes historiadores do pensamento político da segunda metade do século XX responde a essa pergunta fazendo distinção sobre o papel do jurista e do historiador. Para o neozelandês J.G.A. Pocock, o jurista olha para o passado em busca de autoridade que possa ser aplicada no presente. Historiadores, por sua vez, olham para o passado e sabem que o que descobrirem pode ser utilizado no presente na forma de autoridade, mas seu motivo primeiro não constitui a busca de autoridade, até mesmo porque, continua Pocock, o historiador pode fazer história pela própria história. ${ }^{6}$

Nessa perspectiva, o uso da história, para o jurista, tende a ter caráter prático. A história necessita ser "utilizável" de algum modo na forma de um argumento jurídico. Como se opera, pois, esse uso? Para Pocock, o papel prático da história é direcionado à "busca de autoridade". A história permite, então, que um argumento jurídico seja justificado por uma autoridade que se encontra no passado. Vejamos como essa "busca de autoridade" funciona no argumento jusinternacionalista para sabermos se a posição de Pocock é plausível.

Um importante historiador do direito americano, Robert Gordon, já dividiu em três as atitudes do jurista ao olhar para o passado. ${ }^{7}$ Para ele, haveria, primeiramente, uma posição estática, que assume que uma norma ou uma prática jurídica possuem significado fixo estabelecido por seus usos no passado. Nesse caso, cabe ao jurista apenas recolher do passado esse significado

5 BEDERMAN, David J. Foreign office international legal history. In: CRAVEN, Matthew; FITZMAURICE, Malgosia; VOGIATZI, Maria (Ed.). Time, history and international law. Leiden: Martinus Nijhoff, 2007. p. 43-64. p. 46.

6 POCOCK, J. G. A. Law, sovereignty and history in a divided culture: the case of New Zealand and the Treaty of Waitangi. McGill Law Journal, Montreal, v. 43, n. 1, p. 481-506, 1998.

7 Para essa classificação, ver GORDON, R. W. The struggle over the past. Cleveland State Law Review, Cleveland, v. 44, n. 2, p. 123-143, 1996. 
fixo. Essa postura se aproxima bastante de um tipo de história muito cultivada no século XIX, que enfatizava o papel do historiador como alguém que procura uma verdade no passado. O talento do historiador, para essa vertente, está em coletar o máximo de material nos arquivos históricos para provar que algo de fato aconteceu ou sempre foi assim.

Em 1983, um notável internacionalista francês, Prosper Weil, publicou um controverso artigo, clamando os internacionalistas a lutarem contra aquilo que ele então chamava de processo de "relativização normativa" no direito internacional. O surgimento de conceitos como soft law, jus cogens e crimes internacionais (hoje conhecidos, no projeto de artigos da Comissão de Direito Internacional da ONU sobre Responsabilidade Internacional, como violações surgidas de uma obrigação peremptória de direito internacional geral) estariam subvertendo a estrutura que o direito internacional possui desde que foi criado pelos Estados. Enquanto a inserção do soft law no direito internacional retiraria deste sua própria natureza normativa, jus cogens e crimes internacionais criariam uma indevida hierarquização de normas, tornando algumas mais importantes que outras. Weil chega a essa conclusão com base na constatação de que o direito internacional tem e continua a ter as mesmas funções desde que surgiu: promover a coexistência e objetivos comuns entre Estados. A manutenção dessas funções tornaria até mesmo "erro" dividir o direito internacional em moderno e clássico. ${ }^{8}$

Independentemente do acerto da análise de Prosper Weil, o certo é que o passado para ele tem claramente uma função de desvelar o que é comum, aquilo que é contínuo no tempo. Evidentemente que o autor sabe que o passar dos anos opera mudanças nas relações sociais, porém ele acredita que há um conjunto de elementos que são estáticos no tempo ou ao menos devem assim se manter, sob pena de subverterem a própria natureza, a essência do direito internacional. Esse tipo de atitude é bastante comum entre os defensores de postura voluntarista no direito internacional, como é o caso de Weil.

Mas Gordon identifica outra atitude do jurista em relação ao passado, caracterizada por ser dinâmica. Aqueles que adotam essa atitude normalmente acreditam que a

8 WEIL, Prosper. Towards relative normativity in international law? American Journal of International Law, Washington, v. 77, n. 3, p. 413-442, 1983. interpretação jurídica não somente varia, como também deve variar com o tempo para se adaptar às mudanças de condições. O internacionalista, de acordo com essa atitude, é considerado agente do progresso. O seu papel consiste em tornar o futuro melhor que o passado. Essa postura também guarda relação, embora muitas vezes não de maneira explícita, com diversas correntes historiográficas do século XVIII e XIX que acreditavam num progresso contínuo da espécie humana - e de suas estruturas sociais.

Para ilustrar essa atitude, tomemos como exemplo um manual muito popular de língua castelhana: Curso de Derecho Internacional Público y Organizaciones Internacionales, de José António Pastor Ridruejo.

Uma das teses principais do autor é que o direito internacional clássico e o direito internacional contemporâneo se distinguem por três características básicas. Enquanto o primeiro possuía as características de liberal, descentralizado e oligárquico, o direito internacional contemporâneo seria um ordenamento jurídico de caráter social, institucionalizado e democrático. Embora Pastor Ridruejo reconheça que nem todas as características do direito internacional clássico desapareceram, não são elas mais aspiradas pela comunidade internacional. ${ }^{9}$

Pastor Ridruejo vai buscar na história a autoridade que sustenta as características do direito internacional contemporâneo. Ora, as características "social, institucionalizado e democrático" somente se afirmam em oposição ao que é "liberal, descentralizado e oligárquico". O direito internacional contemporâneo precisa do seu oposto (o direito internacional clássico) para se afirmar. O passado necessita do presente para ser superado e o presente necessita do passado para ser justificado. $\mathrm{O}$ passado, assim, se articula continuamente ao presente.

Embora a postura dinâmica tenha a aparência de enfatizar as descontinuidades (o novo e o velho direito internacional), ela também se fundamenta em grandes continuidades. Aqui, o presente se liga de maneira inseparável ao passado e se torna uma consequência, um resultado daquilo que aconteceu anos ou séculos atrás.

As duas atitudes descritas acima têm em comum o fato de buscarem legitimar o presente por meio do passado, mas se utilizam de meios diferentes. No caso da

9 PASTOR RIDRUEJO, José António. Curso de derecho internacional público y organizaciones internacionales. 6. ed. Madrid: Tecnos, 1996. 
atitude estática, o passado deve ser conhecido para que o presente e o futuro continuem a ser como ele; em relação à atitude dinâmica, o passado deve ser conhecido para que o presente e o futuro sejam diferentes dele.

Para essas duas atitudes, fica claro para que serve a história do direito internacional: para, ainda que de maneiras diferentes, legitimar argumento, norma ou proposta sobre a organização jurídica internacional. Isso nos faz voltar à diferença entre o papel do jurista e o do historiador segundo J.G.A. Pocock, que crê que o primeiro apenas busca autoridade no passado.

A caracterização de Pocock é bastante adequada no momento em que consegue perceber que o passado, para o jurista, se articula a uma dimensão prática. É realmente raro um internacionalista fazer história do direito internacional por mero diletantismo, sem propósito concreto no mundo real. Uma história pela história do direito internacional até mesmo subverteria um sentido muito prático que a ciência do direito possui e de que não pode abrir mão. Entretanto, a posição de Pocock não faz justiça a uma série de esforços que têm sido empreendidos por diversos historiadores do direito (inclusive do direito internacional) de conceber o seu próprio papel de maneira diferente. É por essa razão que é possível falar em uma terceira atitude do jurista em relação ao passado: aquilo que Gordon chama de atitude crítica. Gostaria de me concentrar nessa terceira postura e explicar as razões pelas quais acredito que ela seja a mais adequada se pretendemos operar mudanças mais profundas no direito internacional em favor daqueles tradicionalmente excluídos, utilizando com mais vigor do aporte interdisciplinar da historiografia.

\section{HISTÓRIA COMO PRÁTICA CRÍTICA}

Uma atitude crítica do jurista em relação ao passado busca essencialmente destruir ou questionar a autoridade de um autor, um argumento ou mesmo uma norma em relação ao presente. Embora a história, dentro de uma postura crítica, ainda precise ser utilizável, não se busca no passado autoridade para corroborar argumento posto no presente. A "utilização" do passado está mais comprometida com a quebra de tradições ou ao menos com sua reconstrução após uma revisitação profunda de seus fundamentos. Certamente pela influência de pensadores como Michel Foucault, a atitude críti- ca na história do direito internacional está muito mais preocupada em analisar as descontinuidades no discurso jurídico internacional do que as continuidades. E este constitui um ponto importante de diferenciação entre as duas atitudes anteriores do jurista (internacionalista) em relação ao passado e a atitude crítica. A busca por descontinuidades tem constantemente levado os historiadores críticos do direito internacional a descobrir não apenas um significado oriundo do passado que persiste no tempo (como no caso da atitude estática) ou um significado do passado que origina e que dá lugar a outro (como no caso da atitude dinâmica), mas a uma multiplicidade de significados que muitas vezes convivem em um mesmo tempo histórico. A descontinuidade também influencia a própria pesquisa histórica e tem estimulado a ideia de que a história do direito internacional pode ser interpretada de diversas formas possíveis. Se não há autoridade específica a ser seguida, a leitura do passado tende a se tornar bastante diversificada.

O importante historiador intelectual americano, Dominick LaCapra, já definiu o seu próprio esforço crítico como uma "investigação e uma interrogação de pressuposições básicas em práticas e formas de pensamento”. As pressuposições, continua LaCapra,

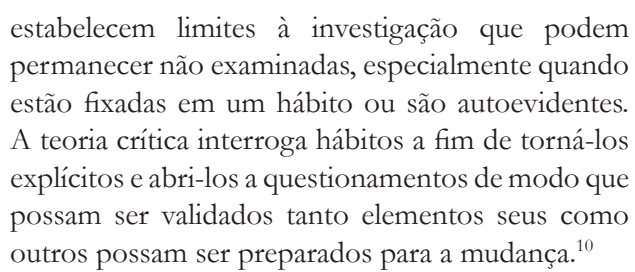

A postura crítica pode, portanto, até mesmo confirmar uma interpretação histórica canônica ou clássica, mas isso somente é feito após profunda investigação sobre os múltiplos sentidos do passado.

Tomemos dois exemplos para demonstrar como essa atitude crítica tem sido desenvolvida no direito internacional.

A narrativa tradicional do processo de universalização do direito internacional consiste naquela que descreve um sistema jurídico internacional inicialmente aplicado a Estados europeus e que, aos poucos, foi se expandindo para o mundo. Esse processo de expansão aconteceu de maneira atrelada a políticas colonialistas que dividiam diversas nações (algumas delas bastante

10 LACAPRA, Dominick. Introduction. In: LACAPRA, Dominick. History and its limits: human, animal, violence. Ithaca: Cornell University Press, 2009. p. 2. 
avançadas do ponto de vista tecnológico e da organização burocrática, como a China e o Japão) em civilizadas, não civilizadas e semicivilizadas. Somente quando o processo civilizacional alcançou as mais diversas partes do globo, foi possível não mais dividir o mundo em categorias civilizacionais. Os povos que antes não gozavam de soberania (por não possuírem um grau civilizacional satisfatório) somente nesse momento passaram a ser reconhecidos como Estados. O reconhecimento como Estado era o pré-requisito para o gozo de direitos básicos na esfera internacional, como a igualdade jurídica. Na síntese de outro manual de direito internacional de língua castelhana bastante popular, o de Remiro Brotóns e outros:

O padrão europeu de civilização como critério determinante de admissão na sociedade internacional permitiu sua extensão para além do Ocidente cristão, mas também forneceu as bases e modelos para a expansão imperialista e colonialista na segunda metade do século XIX na África, Ásia e Oceania. ${ }^{11}$

A esse tipo de interpretação histórica canônica do processo de expansão do direito internacional, Antony Anghie, um autor associado às chamadas TWAIL (Third World Approaches to International Law), com uma perspectiva bastante crítica da história do direito internacional, oferece uma visão profundamente diferente.

Para Anghie, essa leitura da expansão da doutrina da soberania do Ocidente para o resto do mundo é enviesada. Em verdade, a doutrina da soberania teria, ela própria, se formado durante o chamado "encontro colonial". Ele chega a essa conclusão, investigando a maneira como um dos "pais" do direito internacional, Francisco de Vitória, tratou a relação entre os povos europeus e os povos indígenas. Ao desenvolver uma série de conceitos relativos ao direito natural e divino, a diferença cultural entre espanhóis e indígenas, a existência de uma razão universal a governar tanto europeus como os nativos americanos, Vitória estaria universalizando maneiras de pensar o mundo que seriam tipicamente espanholas (e europeias) para compreender e assimilar os povos colonizados. A doutrina da soberania, assim, teria se formado com base na sua oposição com o "outro”, o não soberano, que, após alguns séculos de assimilação, também se tornará soberano. A manobra para

11 REMIRO BROTÓNS, António et al. Derecho internacional: curso general. Valencia: Tirant lo Blanch, 2010. p. 48. dividir o mundo em civilizado e não civilizado teria, então, se iniciado muitos antes do século XIX. Os "pais" do direito internacional, de uma maneira diferente, já confirmavam essa diferença e submetiam os povos não civilizados a uma série de princípios e normas desenvolvidas não de mútuo acordo entre as diversas nações de mundo, mas de maneira unilateral. ${ }^{12}$

Por que Antony Anghie precisa levar adiante essa interpretação pouco convencional da obra de Vitória e do surgimento da doutrina da soberania? Uma das possíveis explicações tem a ver com o objetivo que a atitude crítica pretende em sua leitura da história do direito internacional. O colonialismo é tradicionalmente analisado como algo absolutamente distante da doutrina dos pais fundadores do direito internacional. ${ }^{13}$ Francisco de Vitória, Francisco Suárez, Alberico Gentili, Hugo Grocius, Samuel Pufendorf e outros são constantemente vistos como seres iluminados que conseguiram sistematizar um conjunto de normas para regular e pacificar as relações entre os Estados. Ao sustentar que o "encontro colonial" está intimamente ligado à doutrina desses autores, Anghie quer demonstrar que o direito internacional "nasceu" marcado pelo colonialismo, pelo estabelecimento da diferença entre o europeu e o não europeu. Se é assim, o colonialismo não constitui somente um produto do século XIX: ele existia, ainda que com outro nome, antes disso, e ainda existe nos dias de hoje, qualquer novo nome que se lhe dê. A interpretação histórica de Anghie confirma que a investigação histórica minuciosa fora dos cânones tradicionais pode mostrar que muito do que nós pensávamos sobre o direito internacional deve ser repensado e realidades que julgávamos superadas persistem em formas diferentes. Assim, ainda que a luta anticolonial que teve seu auge nas décadas de 1950, 1960 e 1970 do século passado tenha chegado ao fim, é possível que o colonialismo ainda não tenha cessado: ele pode ser parte integrante da própria estrutura do direito internacional.

12 ANGHIE, Antony. Imperialism, sovereignty and the making of international law. Cambridge: Cambridge University Press, 2007. p. 13-31. 13 Mesmo sem adotar uma postura de crítica pós-colonialista como faz Anghie - é possível perceber que a recepção dos autores clássicos do direito internacional trouxe consigo vários anacronismos que pretendiam justificar agendas do presente. A discussão sobre a "paternidade" do direito internacional, por exemplo, é bastante elucidativa do viés que gerações distintas de internacionalistas deram à obra de autores como Vitória, como muito bem lembra MACEDO, Paulo Emílio Vauthier Borges de. O mito de Francisco de Vitória: defensor dos índios ou patriota espanhol? Revista de Direito Internacional, Brasília, v. 9. n. 1, p. 1-13, 2012. 
Outro exemplo é The Gentle Civilizer of Nations, de Martti Koskenniemi, um dos livros mais influentes de história do direito internacional das últimas décadas.

Uma das narrativas mais tradicionais sobre o desenvolvimento do direito internacional é que ele teve início ou modificou-se bruscamente com a Paz de Westphalia. Esse evento, ao pôr fim ao menos às principais guerras religiosas existentes na Europa após a reforma protestante, teria criado um sistema racional de Estados informado por princípios como liberdade de um soberano de professar determinada religião (cristã), a força obrigatória dos tratados e, principalmente, pela igualdade jurídica entre os Estados. Esses princípios, inicialmente restritos às nações europeias, teriam feito surgir um direito comum aplicado às distintas soberanias na Europa (Droit Public de l'Europe) que, especialmente a partir do século XIX, como já visto em outra narrativa tradicional, teriam se expandido para o resto do mundo. Westphalia, dentro de tal narrativa histórica, revela, assim, "a vontade consciente de uma liga internacional de criar um direito comum e de lhe garantir por meio dos esforços conjuntos de todos". ${ }^{14} \mathrm{O}$ direito internacional contemporâneo seria, portanto, herdeiro direto dos princípios e da mentalidade estabelecida com a Paz de Westphalia.

Koskenniemi não nega a importância de Westphalia para o direito internacional. A originalidade de sua interpretação, no entanto, está em afirmar que não há uma continuidade estrita entre a Paz de Westphalia e o direito internacional atual. De fato, como afirma, poucos perceberam que, na segunda metade do século XIX, uma nova sensibilidade teria surgido entre os especialistas de direito internacional, uma sensibilidade que não existia nos "pais" do direito internacional, como Grocius, nem em figuras importantes posteriores, como Vattel, Von Martens e Wheaton. A essa sensibilidade Koskenniemi chamou de "espírito de internacionalidade" (esprit d'internationlitê). Nas palavras de Koskenniemi, ela "buscava o progresso social, enfatizava a responsabilidade e procurava um meio-termo entre o individualismo e o coletivismo, a especulação abstrata e a ação política". O esprit d'internationalité era, todavia, repleto de grandes contradições: era ao mesmo tempo democrático e temerário das massas, reformista e burguês, nacionalista e in-

14 REDSLOB, Robert. Histoire des grands principes du droit des gens. Paris: Librairie Arthur Rousseau, 1923. p. 216. ternacionalista, progressista e conservador. ${ }^{15}$ Seja como for, para Koskenniemi, tal espírito diferente que surgiu na segunda metade do século XIX chegou ao fim nos anos de 1960, quando o direito internacional passou a ser informado por uma visão mais pragmática em relação ao diversos problemas.

Embora a interpretação de Koskenniemi seja controversa, sua atitude crítica no que diz respeito à história do direito internacional reside em perceber grandes quebras ou descontinuidades em relação à maneira como o direito internacional era pensado antes da segunda metade do século XIX. O autor não está propriamente interessado em provar que o esprit d'internationalité é uma consequência ou desenvolvimento da mentalidade que informava os internacionalistas desde a Paz de Westphalia (como pretenderia a atitude dinâmica) nem sustentar que certas tradições se mantêm no direito internacional (como buscaria a atitude estática). Ele se fixa em um momento histórico preciso em que uma nova episteme, uma maneira de pensar diferente, surgiu. Essa episteme é, ela mesma, repleta de contradições, significando muitas coisas ao mesmo tempo.

Essa maneira crítica de encarar a história do direito internacional é explicada pelo próprio Koskenniemi como um "ato político". Trata-se não de narrativa neutra sobre como o passado de fato foi, "mas uma descrição que espera tornar a nossa situação presente mais clara para nós e afiar nossa própria habilidade para agir nos contextos profissionais que nos são abertos". ${ }^{16}$

Esses são dois exemplos de como a história do direito internacional pode ser lida de maneira a contrariar ou desconcertar interpretações estabelecidas por leituras tradicionais ou canônicas do passado da disciplina.

No entanto, é preciso perceber que o exercício de uma atitude crítica em relação à história do direito internacional exige constante reflexão sobre dois temas importantes: a relação entre história e teoria e a relação entre a escrita da história e a ética. Em verdade, para que a atitude crítica compreenda a si própria e os próprios problemas que dela podem surgir, é preciso que ela radicalize sua agenda, ou seja, possa criticar o próprio fazer

15 KOSKENNIEMI, Martti. The gentle civilizer of nations: the rise and fall of international law 1870-1960. Cambridge: Cambridge University Press, 2001. p. 18-19.

16 KOSKENNIEMI, Martti. The gentle civilizer of nations: the rise and fall of international law 1870-1960. Cambridge: Cambridge University Press, 2001. p. 10. 
crítico. Os dois temas acima mencionados - teoria e ética - servem para exemplificar como a atitude crítica pode permitir que a história seja objeto de mudança do presente e do próprio futuro, também levando em consideração as gerações passadas.

\subsection{História crítica do direito internacional e teoria}

Os historiadores críticos do direito internacional, embora tenham praticado muito dos postulados de uma teoria crítica da sociedade e do conhecimento em seus escritos, pouco têm se dedicado a refletir sobre o próprio fazer histórico. Pouco se vê, por exemplo, como a construção de narrativas tem afetado o fazer histórico no direito internacional. Também não se explicita, com mais profundidade, sobre a função da história, perguntando-se, por exemplo, para que ela existe ou serve. E determinadas noções, como direcionalidade e causalidade históricas, objetividade e progresso são pouquíssimo estudadas pelos historiadores do direito internacional. É verdade que muitas dessas questões são tratadas indiretamente pelos autores, mas uma reflexão mais sistemática sobre elas é necessária.

Mas para que serve a teoria para a história do direito internacional? Essa pergunta é das mais importantes e não está restrita ao domínio da história jurídica. Nas últimas décadas, diversos historiadores profissionais têm se insurgido contra o que têm chamado de excesso de teorização da historiografia recente. O historiador Keith Windschuttle, por exemplo, fez enorme sucesso com a publicação de The Killing of History: How Literary Critics and Social Theorists are Murdering our Past (O assassinato da história: como críticos literários e teóricos sociais estão assassinando nosso passado). Ele argumenta, dentre outras coisas, que retirar conclusões com base nas grandes generalizações ou de qualquer coisa que se pareça com leis históricas procedimentos típicos de alguém considerado como um teórico — fugiria à abordagem propriamente histórica. Windschuttle também ressalta a necessidade de a história repousar em conceitos como objetividade e verdade algo combatido especialmente por historiadores influenciados por teorias pós-modernas. ${ }^{17}$

O que pretendem essas posições altamente des-

17 WINDSCHUTTLE, Keith. The killing of history: how literary critics and social theorists are murdering our past. San Francisco: Encounter Books, 2000. p. 16-17; 203-250. confiadas da história mais teorizada é que a busca do passado se restrinja ao domínio do relativo, aquilo que não pode ser generalizado. $\mathrm{O}$ dado histórico não se repete, ele é único. Não se pode tratar o passado como as maçãs que, submetidas às mesmas condições, caem pela força da gravidade. Ao mesmo tempo, tais posições creem que existe conhecimento histórico específico a ser escavado e que o historiador não pode se deixar influenciar por ideologias ou preconcepções que de algum modo afetem a pesquisa que empreenderá.

Essa insurgência contra a teoria possui razões legítimas. Uma teoria pouco problematizada pode desvirtuar a própria ideia de conhecimento histórico. O argumento marxista, por exemplo, muitas vezes esqueceu-se das várias peculiaridades do passado por conta da necessidade de justificar uma ideia abstrata: A luta de classes que se repete no tempo e no espaço. $\mathrm{O}$ argumento liberal, por sua vez, diversas vezes transplantou o moderno conceito de liberdade para povos que não o conheceram. Os juristas constantemente pretendem justificar suas teorias com base em exemplos históricos pouco contextualizados. O direito internacional proporciona um bom exemplo: muitos autores costumam exemplificar o surgimento do princípio pacta sunt servanda naquele documento considerado como o primeiro tratado do mundo (O tratado de paz celebrado entre Hatusil III, rei dos hititas, e Ramsés II, faraó egípcio, entre 1280 e 1272 a.C.). Argumentos como esse servem mais para justificar que o direito dos tratados possui uma longa história e pouco se preocupam em perceber se existia direito internacional bem identificável na Antiguidade clássica e, em caso afirmativo, que tipo de direito internacional existia então. Esse tipo de postura, que pode ser chamada de teoricismo, permanece em um nível muito especulativo, puramente conceitual e é normalmente autorreferente - no sentido de prestar pouca atenção aos fatos. ${ }^{18}$

Mas a história não pode nem deve se afastar da teoria. É ela quem permite testar e contestar categorias e expandir o alcance de várias possibilidades conceituais e imaginativas. ${ }^{19}$

18 LACAPRA, Dominick. Articulating intellectual history, cultural history, and critical theory. In: LACAPRA, Dominick. History and its limits: human, animal, violence. Ithaca: Cornell University Press, 2009. p. 13-36. p. 30-32. LaCapra fornece alguns exemplos de obras históricas recentes que recaem nessa postura com base nos conceitos elaborados por teóricos como Lacan (o real), Lyotard (différend) ou Agamben (homo sacer).

19 LACAPRA, Dominick. Articulating intellectual history, cultur- 
Tomemos mais um exemplo para mostrar a importância da teoria para a história.

Alfred Verdross, em seu clássico manual Völkerrecht, decide iniciar o estudo do direito internacional pela chamada "comunidade cristã de Estados". Ele explica essa opção do seguinte modo:

Por outrolado, não há que se desconsiderar o impacto de outros dois círculos jurídicos internacionais, a saber: o bizantino e o islâmico sobre o Ocidente medieval. Contudo, nós não o levaremos em conta, porque, em geral, sua influência sobre a constituição do direito internacional moderno foi escassa. ${ }^{20}$

Esse recorte histórico adotado por Verdross demonstra didaticamente a necessidade de maior teorização para a história do direito internacional. Primeiramente, o que o autor quer dizer com círculos jurídicos internacionais? Tratar-se-ia de ordens jurídicas autônomas? Elas poderiam ser consideradas "outros" direitos internacionais"? O que significa propriamente impacto e influência de um círculo jurídico internacional em outro? Houve apenas um Ocidente medieval? A oposição entre medieval e moderno não carrega em si uma ideologia progressista, tornando o passado menos importante que o presente? Por que, enfim, a história do direito internacional deve ser contada tomando-se por base a Europa, quando coexistiam outros círculos jurídicos internacionais? O que significa, para a escrita da história do direito internacional hoje, o escasso conhecimento sobre a história de círculos jurídicos internacionais "alternativos" ao direito internacional moderno (e europeu)?

Alguns autores têm tentado responder a essas perguntas. Para tanto, eles têm precisado enveredar por uma série de questões teóricas que dizem respeito ao impacto de diferentes civilizações no desenvolvimento do direito internacional. Onuma Yasuaki, por exemplo, ao defender a sua perspectiva trans-civilizacional da história do direito internacional tem precisado responder a perguntas como: o que é uma sociedade internacional? O que significa uma perspectiva internacional em relação a uma perspectiva transnacional? Qual a relação entre poder e direito internacional? $\mathrm{O}$ que quer dizer a ocidentalização do direito internacional e o

al history, and critical theory. In: LACAPRA, Dominick. History and its limits: human, animal, violence. Ithaca: Cornell University Press, 2009. p. 13-36. p. 32.

20 VERDROSS, Alfred. Derecho internacional público. 4. ed. Madrid: Aguilar, 1961. p. 34. eurocentrismo? ${ }^{21}$ Os arquivos históricos sozinhos não conseguem responder a essas perguntas. Mais que isso, elas exigem, por parte de jusinternacionalistas, tomadas de posição que certamente podem ofender um historiador muito cioso da necessidade de manter a sua própria objetividade.

A verdade é que é virtualmente impossível fazer história sem qualquer tipo de teoria. Essa teoria pode ser de diversos tipos, pouco problematizadora ou muito problematizadora; pouco crítica ou muito crítica. O que a história do direito internacional realmente necessita constitui abrir portas para a compreensão do mundo que nos rodeia. Para mais uma vez lembrar LaCapra, a história (crítica) do direito internacional necessita criar mentalidade que possa lidar com temas bastante complexos com a consciência de que passado e presente interagem e que eles podem ser direcionados para uma abertura de diversos futuros possíveis. ${ }^{22} \mathrm{E}$ essa mentalidade não pode ser criada sem aporte robusto de teoria.

O jusinternacionalista deve estar preparado para encarar a história do direito internacional como "o produto de um campo de forças de impulsos frequentemente conflitantes, puxando-o de uma maneira ou de outra, e pondo mais questões do que pode responder". ${ }^{23}$ Isso quer dizer que muitas das perguntas que se põem, na investigação histórica, podem não ser resolvidas ou, às vezes, podem trazer mais de uma solução ao mesmo tempo. Um autor ou uma norma do passado não são oriundos de um pensamento completamente naturalista ou positivista, liberal ou marxista, libertário ou conservador. Essas forças contraditórias persistem na sociedade de hoje e do passado e moldam as coisas e os seres. Preparar-se para encarar essas contradições e complexidades significa situar-se e posicionar-se no mundo, e as teorias nos auxiliam nessa tarefa. Certo que aquele que escreve a história do direito internacional (ou qualquer história) não está autorizado a manipular fatos, imaginar aquilo que não existiu. Ele, porém, lê esses fatos

21 ONUMA, Yasuaki. A transcivilizational perspective on international law: questioning prevalent cognitive frameworks in the emerging multi-polar and multi-civilizational world of the twentyfirst century. Recueil des Cours de l'Académie de Droit International de la Haye, La Haye, v. 342, p. 77-410, 2009.

22 LACAPRA, Dominick. Articulating intellectual history, cultural history, and critical theory. In: LACAPRA, Dominick. History and its limits: human, animal, violence. Ithaca: Cornell University Press, 2009. p. 13-36. p. 17.

23 JAY, Martin. Introduction. In: JAY, Martin. Force fields: between intellectual history and cultural critique. London: Routledge, 1993. p. 1-9. p. 3. 
com pré-compreensões que trouxe consigo. É seu dever tornar explícitas essas pré-compreensões e permitir, assim, que outras histórias sejam escritas com outros tipos de pré-compreensões. Saber que há histórias diferentes porque as pessoas pensam de maneira diferente é o que constitui a nossa própria liberdade, a possibilidade de sermos, enfim, diferentes.

A história crítica do direito internacional deve, portanto, considerar a contribuição que a teoria pode oferecer na construção de narrativas históricas. E a teoria também pode oferecer à história crítica constante reflexão sobre seus próprios pressupostos e mudanças de caminho porventura necessárias para tornar a história um exercício de pluralismo e, porque não dizer, de construção da liberdade. A ausência de preocupações teóricas pode muitas vezes levar o historiador a naturalizar suas narrativas, acreditar que elas são como deveriam ser quando, de fato, elas poderiam ser lidas de diversas maneiras.

Assumir a importância da teoria significa tomar opções no mundo, opções que interferirão na escrita da história. E isso nos leva a outra questão, também bastante importante para o projeto da história crítica do direito internacional: a ética.

\subsection{História crítica do direito internacional e ética}

Como vimos acima, historiadores de grande renome, como J.G.A. Pocock, admitem que a história pode ser feita sem nenhum propósito específico: a história pela própria história.

Uma postura desse tipo é perfeitamente compreensível. Durante o século XX, diversos historiadores perceberam que sua própria independência havia sido comprometida. Em nome de ideais como patriotismo, vinculação política ou nacionalismo, a narrativa histórica serviu para legitimar relações de poder. A própria experiência de Estados totalitários demonstrou como a história poderia ser manipulada para interesses específicos. Uma reação a esse estado de coisas foi a adoção de postura mais neutra. A história não serviria a ninguém, senão a si própria: a história deveria ser feita em nome da própria história. A verdade histórica seria aquilo com o que realmente os historiadores deveriam se preocupar. ${ }^{24}$

24 SOUTHGATE, Beverley. What is history for? London: Routledge, 2005. p. 18-19.
Essa postura tem relação profunda com o tema já mencionado da necessidade de uma objetividade por parte do historiador. Ser objetivo consiste em deixar a história falar por si própria. Esse tipo de postura, entretanto, embora possua suas justificativas, provoca, ela mesma, diversas incompreensões. Gostaria de ressaltar duas delas.

Primeiro, ela gera o que um importante filósofo da história holandês, Frank Ankersmit, já chamou de "duplo dilema" (double bind). A objetividade na história exige que o historiador retire a sua subjetividade na construção de narrativas, ou seja, deixe de lado, dentre outras coisas, seus valores morais e políticos. Acontece que essa separação entre o objetivo (o passado) e o subjetivo (o historiador) tende a se dissolver. Isso porque não são apenas os valores morais e políticos do historiador que podem afetar o passado; também os valores morais existentes no passado narrado por um historiador podem invadir o seu mundo e o de seus contemporâneos. Não é possível tornar completamente objetivos esses valores morais e políticos que existiam no passado. Eles não podem ser simplesmente tratados como objetos porque podem interferir na subjetividade do historiador (fazendo-o mudar seus valores ou adotar novos com base na pesquisa que efetuou sobre o passado). Exatamente nisso consiste o "duplo dilema" do historiador. Se ele decide ser objetivo na investigação do passado, recairá em subjetivismo, porque estará simplesmente negando aqueles valores morais e políticos que existem no passado, numa espécie de "subjetivismo invertido". Ankersmit exemplifica essa postura como alguém que grita: "Não olhe para mim! Eu não estou aqui! Eu não existo!" E se, por outro lado, o historiador decide admitir que seus valores morais e políticos interferem nas suas narrativas históricas, ele estará incorrendo em subjetivismo. Nesse sentido, é extremamente artificial dividir o objetivo e o subjetivo nas narrativas históricas. ${ }^{25}$

Segundo, é certo que existem fatos incontroversos na história: determinadas coisas aconteceram e outras não - a queda de Impérios, o assassinato de chefes de Estado, o Holocausto... E um historiador consciente de sua função na sociedade não está autorizado a deturpar esses fatos. Mas o historiador, quando traz esses fatos para o presente, ele ou ela cria outra realidade que não mais existe. Sua narrativa constitui algo verdadeiramen-

25 ANKERSMIT, F. R. The ethics of history: from the double binds of (moral) meaning to experience. History and Theory, Middletown, v. 43, n. 4, p. 84-102, 2004. 
te novo no presente com base em um dado do passado. Se é assim, essa nova realidade terá algumas cores que estabelecem o que constitui o cenário que circunda o historiador. Dizer que existe objetividade total do historiador é negar-se a perceber esse cenário circundante. Diversas narrativas históricas trazem em si diferentes agendas escondidas, algumas delas conscientemente, outras subconscientemente. Por exemplo, o desejo de formar uma nação ou uma comunidade internacional, a pouca relevância concedida ao papel das mulheres, o esquecimento da contribuição de determinados grupos no passado, especialmente aqueles mais excluídos, interferem na escrita da história. Se a existência desse cenário que circunda o historiador é inevitável, que ao menos ele se esforce ao máximo para deixá-lo claro, que seus interesses - ao menos aqueles conscientes - se mostrem ao leitor. Isso nos permitirá aceitar a sua narrativa ou optar por outra explicação do passado elaborada por um historiador diferente. ${ }^{26}$ A transparência é, portanto, um valor ético importante que deve ser cultivado pelos historiadores críticos do direito internacional.

O historiador crítico do direito internacional também possui importante função ética de apresentar o passado não como ele naturalmente é, mas como o historiador o vê. ${ }^{27}$ Trata-se de compromisso com o pluralismo de valores e o pluralismo de narrativas. Não há interpretações infalíveis ou indiscutíveis. O passado pode (e deve) ser visto de maneiras diferentes. O seu dever não é para com o assunto histórico por ele tratado, mas para com os seus leitores. ${ }^{28}$ São eles que retirarão conclusões tomando-se por base o trabalho lido e perceberão o que o passado ilumina ou não. É fundamentado no cultivo dessa pluralidade que o historiador abre diversas possibilidades para a construção do futuro. A interpretação histórica que alega ser incontestável antecipa e controla o próprio futuro. Um dos principais fundamentos da teoria crítica é a de um futuro aberto. A ética da crítica, portanto, se funda na ideia de uma história indetermi-

26 ANKERSMIT, F. R. The ethics of history: from the double binds of (moral) meaning to experience. History and Theory, Middletown, v. 43, n. 4, p. 84-102, 2004.

27 Com isso, não pretendo afirmar que as demais atitudes excluem uma atitude ética. Contudo, na maior parte das vezes, elas não são conscientes disso ou partem do pressuposto de que há uma distância significativa entre o estudioso da história e o objeto de seu estudo.

28 SOUTHGATE, Beverley. A pair of white gloves: historians and ethics. Rethinking History, London, v. 10, n. 1, p. 49-61, 2006. p. $53 ; 59$. nada. ${ }^{29}$ Não é à toa que na introdução de seu The Gentle Civilizer of Nations, Martti Koskenniemi diz claramente que a sua narrativa

[...] não busca uma descrição neutra do passado 'como ele realmente foi' - esse tipo de conhecimento não é aberto a nós - mas uma descrição que busca tornar a situação presente mais clara para nós enquanto nos envolvemos em nossas práticas e projetos. Nesse sentido, constitui também um ato político: $:^{30}$

O projeto de uma história crítica, para realizar a ideia de uma história indeterminada, precisa levar em conta que o futuro "é garantido somente pela persistente insatisfação da crítica”. ${ }^{31}$ Esse projeto ético precisa levar em conta o presente. É justamente na ligação entre presente e passado que o futuro se torna viável. A despreocupação com o presente faz com que a história possa ser escrita "para a própria história", contribuindo, assim, diversas vezes, para a manutenção do status quo. As demandas do presente são essenciais para a história se se pretende que ela tenha um caráter revolucionário, mostrando que as coisas poderiam ter sido de maneira diferente e que a tradição não constitui uma prisão que nos impeça de pensar mundos alternativos.

A crítica tem, portanto, compromisso ético importante com o presente. É por isso que muitos historiadores críticos do direito internacional têm tentado articular o passado nas suas diversas teorizações sobre o direito internacional contemporâneo. Apresentarei brevemente apenas dois exemplos dessa tendência.

Um dos primeiros estudos, abordando de maneira sistemática uma visão crítica do direito internacional, o artigo de David Kennedy, A New Stream of International Law Scholarship, traça relação estreita entre história e teoria. Para Kennedy, o direito internacional demonstra padrões argumentativos — padrões de contradição e de solução, de diferença e de homologia. A doutrina, a história e a própria estrutura institucional que envolve o direito internacional reafirmam aqueles padrões de maneira repetida. Ora, para investigar como operam esses padrões, o estudo da história era e é essencial para

29 SCOTT, Joan W. History-writing as critique. In: JENKINS, Keith; MORGAN, Sue; MUNSLOW, Alun (Ed.). Manifestos for history. London: Routledge, 2007. p. 24.

30 KOSKENNIEMI, Martti. The gentle civilizer of nations: the rise and fall of international law 1870-1960. Cambridge: Cambridge University Press, 2001. p. 10.

31 SCOTT, Joan W. History-writing as critique. In: JENKINS, Keith; MORGAN, Sue; MUNSLOW, Alun (Ed.). Manifestos for history. London: Routledge, 2007. p. 34. 
a perspectiva de Kennedy. De fato, em diversas obras posteriores, o autor se debruçou sobre a história da disciplina para mostrar que aqueles padrões realmente existiam. $^{32}$

Mais recentemente, a internacionalista finlandesa Outi Korhonen propôs a ideia de "situacionalidade" para compreender o papel do jurista internacionalista. Essa "situacionalidade" somente pode ser compreendida com o auxílio de diversos aspectos que fogem da dimensão estritamente jurídica, mas que afetam os juristas na construção de suas ideias, como a cultura e a história. Essa história, no entanto, não possui um único significado, ela pode ser abordada de diferentes maneiras. ${ }^{33}$

Não é exclusividade dos autores críticos envolverem história e teoria. Como já afirmado anteriormente, diversos teóricos do direito internacional buscam na história a autoridade para confirmarem as suas teorias. A originalidade da abordagem crítica, no entanto, está em destruir ou mesmo questionar a autoridade de um autor, um argumento ou mesmo uma norma em relação ao presente. Mas essa atitude não é feita por um simples desejo de romper com as verdades estabelecidas, ela surge de um compromisso ético em mudar o estado de coisas atual com base na investigação do passado. $\mathrm{O}$ dever ético chama o crítico a ser inconformado com o status quo. Como afirma um historiador associado a correntes pós-modernas, Keith Jenkins, ao se referir às ideias de Edward Said: o intelectual (aí também se incluindo o historiador)

é uma pessoa que gosta de estar não completamente
ajustado, de existir, com felicidade, para além da
coloquial e inconsequente 'realidade' habitada pelos
nativos, de permanecer imune ao comodismo: uma
pessoa não cooptável, desobediente. ${ }^{34}$

Esse inconformismo deve se referir não apenas ao status quo vigente, mas ao status quo que já passou. $\mathrm{O}$ historiador crítico tem também contas a prestar com aqueles que já se foram. Por isso, uma das funções da história consiste em proporcionar o "outro". Do mesmo modo que muito do pensamento contemporâneo tem buscado entender, por exemplo, os estrangeiros,

32 KENNEDY, David. A new stream of international law scholarship. Wisconsin International Law Journal, Madison, v. 7, n. 1, p. 1-49, 1988. 33 KORHONEN, Outi. International law situated: an analysis of the lawyer's stance towards culture, history and community. The Hague: Kluwer, 2000. p. 129-206; 295.

34 JENKINS, Keith. Ethical responsibility and the historian: on the possible end of a history 'of a certain kind'. History and Theory, Middletown, v. 43, n. 4. p. 43-60, 2004. p. 57. Ênfases do original. os escravos ou os povos primitivos e colonizados, é preciso compreender também esses "outros", cronologicamente falando: aqueles escondidos nas narrativas oficiais, aqueles cuja memória foi reprimida ou mesmo suprimida, aqueles que ficaram esquecidos no tempo ${ }^{35}$. Somente assim se poderá fazer justiça a eles. Como afirmou Walter Benjamin: "existe um ponto de encontro misterioso entre as gerações passadas e a nossa: fomos esperados sobre a terra". ${ }^{36}$

\subsubsection{Historiografia do direito internacional, colo- nialismo e eurocentrismo}

Um debate contemporâneo que muito envolve a questão da ética na historiografia do direito internacional merece ser mencionado neste artigo.

Nos últimos anos, em especial entre autores ligados a correntes críticas, muito se tem falado sobre a influência do colonialismo e da Europa na formação do direito internacional como o conhecemos hoje. Não há dúvidas de que uma parte considerável dessa literatura é fruto dos esforços de autores ligadas às já mencionadas TWAIL. ${ }^{37}$ Os autores ligados às TWAIL partem do pressuposto de que a história do direito internacional é essencial para o estudo da disciplina e de que a Europa, com suas políticas colonialistas, a influenciou de maneira inescapável. No entanto, é perceptível um interesse no tema também em autores não necessariamente ligados a essas abordagens terceiro-mundistas. ${ }^{38}$

Ante essa tendência nos estudos historiográficos críticos do internacional, a grande questão que se coloca não é saber se o colonialismo influenciou o direito internacional, mas o quanto de influência o primeiro exerceu no segundo e se tal influência ainda persiste.

35 SOUTHGATE, Beverley. What is history for? London: Routledge, 2005. p. 120.

36 MATE, Reyes. Medianoche en la historia: comentarios a las tesis de Walter Benjamin 'sobre el concepto de historia'. Madrid: Trotta, 2006. p. 67.

37 GATHII, James Thuo. TWAIL: a brief history of its origins, its decentralized network, and a tentative bibliography. Trade, Law and Development, Jodhpur, v. 3, n. 1, p. 26-64, 2011.

38 KOSKENNIEMI, Martti. Histories of international law: dealing with eurocentrism. Rechtsgeschichte, Frankfurt, v. 19, p. $152-$ 176, 2011 e ORFORD, Anne. The past as law or history? the relevance of imperialism for modern international law. In: TOUFAYAN, Mark; TOURME-JOUANNET, Emmanuelle; RUIZ FABRI, Hélène (Ed.). Droit international et nouvelle approches sur le Tiers-Monde: entre repetition et renouveau. Paris: Societé de Législation Comparée, 2013. p. 97-117. 
Nessa questão, dois tipos de postura podem ser facilmente identificadas - um debate que remonta aos estudos sobre pós-colonialismo em geral. Há aqueles que acreditam que o direito internacional é tão impregnado por estruturas coloniais, que não se pode pensá-lo sem essas. Nesse sentido, não haveria saída para o direito internacional fora do colonialismo ou de suas novas formas. Outros, por sua vez, entendem que o direito internacional pode superar a herança (perniciosa) do colonialismo no direito internacional. ${ }^{39}$

Tal divergência reverbera, no âmbito dos estudos historiográficos do direito internacional, no problema de saber como o historiador do direito internacional deve encarar as ideias de colonialismo e Europa na composição de suas narrativas. Autores como Anghie parecem entender que fazer história do direito internacional está invariavelmente ligado a fazer a história do colonialismo, pois, como afirmado acima, para esse autor, o direito internacional se formou no próprio "encontro colonial". Outros, como Koskenniemi, embora não fujam da constatação de que toda a historiografia do direito internacional feita até então possui o traço de eurocentrismo e o colonialismo que dele decorre — até mesmo a literatura ligada às TWAIL teria certa carga de eurocentrismo, sustenta - percebem algum espaço para a superação dessa marca. ${ }^{40}$

Outro conjunto de autores, ao reconhecer a importância do estudo do eurocentrismo e do colonialismo no direito internacional, concebe, de maneira mais clara que o próprio Koskenniemi, a possibilidade de sua superação. Tais autores buscam trazer para o campo jurídico internacional a contribuição, em especial, da chamada "história global", que se tornou bastante conhecida principalmente pela contribuição de historiadores alemães. Esse tipo de historiografia se concentraria nas diversas interações que ocorreram em nível global e

39 Ver GATHII, James Thuo. International law and eurocentricity. European Journal of International Law, Firenze, v. 9, n. 1, p. 184-211, 1998. Recentemente o ex-juiz da Corte Internacional de Justiça e representante da chamada primeira geração de TWAILers, Mohammed Bedjaoui, demonstrou uma certa esperança em ver o direito internacional desconectado da ideia de colonialismo. BEDJAOUI, Mohammed. Observations sur le texte d'Antony Anghie. In: TOUFAYAN, Mark; TOURME-JOUANNET, Emmanuelle; RUIZ FABRI, Hélène (Ed.). Droit international et nowvelle approches sur le TiersMonde: entre repetition et renouveau. Paris: Societé de Législation Comparée, 2013. p. 89-91.

40 KOSKENNIEMI, Martti. Histories of international law: dealing with eurocentrism. Rechtsgeschichte, Frankfurt, v. 19, p. 152-176, 2011. p. 168 local entre diferentes tipos de atores sociais no tempo. Assim, tanto a chamada "periferia" teria influenciado o "centro" do mundo como vice e versa. A maior parte dos historiadores globais não consegue ver, diferentemente dos pós-colonialistas, que as relações sociais entre diferentes atores em diferentes partes do mundo tenham se dado exclusivamente ou eminentemente por meio de subjugação do mais forte pelo mais fraco. A maior tentativa de trazer o debate sobre a história global no direito internacional se deu com a publicação do The Oxford Handbook of the History of International Law, ${ }^{41}$ obra organizada por dois autores também alemães: Anne Peters e Bardo Fassbender.

O debate sobre colonialismo e eurocentrismo na historiografia do direito internacional possui o grande mérito não apenas de visibilizar o sofrimento de pessoas e povos durante o tempo, mas também de atribuir à história do direito internacional o importante papel de auxiliar na construção de agendas para o presente. Quando se fala na persistência ou superação do colonialismo no direito internacional, estabelece-se, também, crítica à manutenção dessas estruturas e a opção por um direito internacional diferente.

É verdade que conectar o presente ao passado pode gerar sérios riscos de um internacionalista ou historiador incorrerem no já mencionado anacronismo. Recentemente, a internacionalista crítica australiana, Anne Orford, ao defender o papel das TWAIL em conectar presente e passado, contestou a importância excessiva que tradicionalmente se tem atribuído à questão do anacronismo com base em uma diferenciação necessária entre história e direito. $\mathrm{O}$ segundo se move eminentemente por prioridades do presente, sustenta ela. ${ }^{42} \mathrm{O}$ zelo em evitar o anacronismo, no entanto, não parece

41 Ver especialmente FASSBENDER, Bardo; PETERS, Anne. Introduction: towards a global history of international law. In: FASSBENDER, Bardo; PETERS, Anne (Ed.). The Oxford handbook of the history of international law. Oxford: Oxford University Press, 2012. p. 1-24. Ver, também, o simpósio dedicado ao livro, publicado no European Journal of International Law, v. 25, n. 1, p. 287-341, 2014, com estudos bastante céticos quanto à aplicação da história global ao direito internacional. KEMMERER, Alexandra. Towards a global history of international law. European Journal of International Law, Oxford, v. 25, n. 1, p. 287-295, Feb. 2014.

42 ORFORD, Anne. The past as law or history? the relevance of imperialism for modern international law. In: TOUFAYAN, Mark; TOURME-JOUANNET, Emmanuelle; RUIZ FABRI, Hélène (Ed.). Droit international et nouvelle approches sur le Tiers-Monde: entre repetition et renouveau. Paris: Societé de Législation Comparée, 2013. p. 97-117. p. 89-91. 
ser a grande questão em jogo. O que se faz com o passado não está no passado. Os usos da história são estabelecidos no presente, possuindo, muitas vezes, funções prospectivas. Soaria inocente a qualquer historiador afirmar que o passado não pode interferir no presente.

Atribuir à pesquisa historiográfica a possibilidade de auxiliar na construção de agendas do tempo presente também reforça a função ética do historiador do direito internacional. Por essa razão, esse debate gira, em última análise, em torno da ética na composição de narrativas históricas. Ainda que discordem quanto aos métodos, pós-colonialistas (boa parte ligados às TWAIL) e historiadores globais do direito internacional concordam que o colonialismo foi pernicioso para as relações internacionais e ele não deve persistir ou ser ressuscitado. Essa é uma opção clara que interfere na construção e confecção de teorias jurídicas internacionais e mesmo na interpretação de problemas concretos práticos da realidade internacional.

Afinal, uma ética de responsabilidade para o historiador do direito internacional deve significar não apenas fiar-se em regras rigorosas da pesquisa historiográfica, mas também viabilizar a possibilidade de mundo diferente.

\section{Considerações finais}

A pergunta "para que serve a história do direito internacional?” depende essencialmente da concepção de história e da concepção de direito internacional que se tem. Neste artigo, identifiquei ao menos três atitudes claras do jurista em relação ao passado que ajudam a respondê-la. As atitudes estática e dinâmica, embora apresentem prioridades diferentes, possuem ponto em comum: ambas buscam no passado certa autoridade para justificar o presente. Uma terceira atitude, denominada crítica, vê o passado como campo aberto, não se comprometendo necessariamente em buscar autoridade para justificar o presente.

Não existe atitude "correta" do jurista em relação ao passado, assim como não existe resposta correta à questão "para que serve a história do direito internacional?". Adotar uma das atitudes significa priorizar alguns elementos na história e, assim, responder de maneira diferente à mencionada pergunta.
Esse autor considera que reduzir a função da história a uma mera legitimação do presente significa, no entanto, conformar-se com a forma e a organização atual do sistema jurídico internacional. O direito internacional está longe de produzir justiça em larga escala para os povos do mundo. Ele serve mesmo para confirmar relações de poder entre Estados, instituições e pessoas ao redor do globo. A história (ou, para ser mais preciso, a historiografia, no sentido daquilo que os historiadores escrevem) tem muito a contribuir para repensar o próprio direito internacional. Ela pode oferecer soluções alternativas, abrir novos caminhos de pesquisa e estimular a criatividade do jurista na solução de problemas globais. Nos dias atuais, a crítica tem se mostrado a atitude que melhor oferece instrumentos para a mudança do direito internacional, especialmente porque não está comprometida diretamente com a busca de uma autoridade para o presente.

A atitude crítica na história do direito internacional, embora já identificada em diversos autores, precisa ser radicalizada. Dois caminhos são importantes para esse fim: um diálogo maior da história com a teoria e a compreensão de que lidar com o passado significa tomar posições no campo da ética. Enquanto a crítica fornece sofisticação à história, permitindo a ampliação de horizontes e reflexão sobre as suas próprias limitações, a ética demonstra que o historiador constitui alguém que está comprometido não apenas com o passado, mas também com o presente e o futuro: o historiador em geral, mas também o historiador do direito internacional constitui alguém que produz aspectos éticos e não apenas os consome. ${ }^{43}$

Levando-se em consideração essa opção pela atitude jurídica crítica em relação ao passado, é possível responder à pergunta contida no título deste artigo. A história do direito internacional serve para indagar ou mesmo romper com tradições estabelecidas, auxiliando o direito internacional a repensar os seus próprios fundamentos; consequentemente, ela permite a construção de diferentes alternativas possíveis para a organização jurídica internacional do presente e do futuro ao levar em consideração uma necessária prestação de contas devida para com as gerações passadas.

43 GORMAN, Jonathan. Ethics and the writing of historiography. In: TUCKER, Aviezer (Ed.). A companion to the philosophy of history and historiography. Chichester: Blackwell, 2009. p. 253-261. p. 260. 
Esta, no entanto, não é nem pode ser uma resposta definitiva, porém apenas provisória. A atitude crítica é, ela própria, sujeita a constantes ajustes e modificações. Esse deve ser o esforço do qual a história do direito internacional não pode abrir mão: estar aberta à revisão, todo o instante, ainda que isso nos traga instabilidade ou nos distancie de nossos amados pais.

\section{RefERÊNCIAS}

ANGHIE, Antony. Imperialism, sovereignty and the making of international law. Cambridge: Cambridge University Press, 2007.

ANKERSMIT, F. R. The ethics of history: from the double binds of (moral) meaning to experience. History and Theory, Middletown, v. 43, n. 4, p. 84-102, 2004.

BEDERMAN, David J. Foreign office international legal history. In: CRAVEN, Matthew; FITZMAURICE, Malgosia; VOGIATZI, Maria (Ed.). Time, history and international law. Leiden: Martinus Nijhoff, 2007. p. 43-64.

BEDJAOUI, Mohammed. Observations sur le texte d'Antony Anghie. In: TOUFAYAN, Mark; TOURMEJOUANNET, Emmanuelle; RUIZ FABRI, Hélène (Ed.). Droit international et nowvelle approches sur le TiersMonde: entre repetition et renouveau. Paris: Societé de Législation Comparée, 2013. p. 89-91.

CRAVEN, Matthew. Introduction: international law and its histories. In: CRAVEN, Matthew; FITZMAURICE, Malgosia; VOGIATZI, Maria (Ed.). Time, history and international law. Leiden: Martinus Nijhoff, 2007. p. 1-26.

FASSBENDER, Bardo; PETERS, Anne. Introduction: towards a global history of international law. In: FASSBENDER, Bardo; PETERS, Anne (Ed.). The Oxford handbook of the history of international law. Oxford: Oxford University Press, 2012. p. 1-24.

FRANCK, Thomas M. Fairness in international law and institutions. Oxford: Oxford University Press, 1998.

GATHII, James Thuo. International law and eurocentricity. European Journal of International Law, Firenze, v. 9, n. 1, p. 184-211, 1998.

GATHII, James Thuo. TWAIL: a brief history of its origins, its decentralized network, and a tentative bibliography. Trade, Law and Development, Jodhpur, v. 3, n. 1, p.
26-64, 2011.

GORDON, R. W. The struggle over the past. Cleveland State Law Review, Cleveland, v. 44, n. 2, p. 123-143, 1996.

GORMAN, Jonathan. Ethics and the writing of historiography. In: TUCKER, Aviezer (Ed.). A companion to the philosophy of history and historiography. Chichester: Blackwell, 2009. p. 253-261.

HATHAWAY, Oona; SHAPIRO, Scott J. Outcasting: enforcement in domestic and international law. Yale Law Journal, New Haven, v. 121, n. 2, p. 252-349, 2011.

JAY, Martin. Introduction. In: JAY, Martin. Force fields: between intellectual history and cultural critique. London: Routledge, 1993. p. 1-9.

JENKINS, Keith. Ethical responsibility and the historian: on the possible end of a history 'of a certain kind'. History and Theory, Middletown, v. 43, n. 4. p. 43-60, 2004.

KEMMERER, Alexandra. Towards a global history of international law. European Journal of International Law, Oxford, v. 25, n. 1, p. 287-295, Feb. 2014.

KENNEDY, David. A new stream of international law scholarship. Wisconsin International Law Journal, Madison, v. 7, n. 1, p. 1-49, 1988.

KORHONEN, Outi. International law situated: an analysis of the lawyer's stance towards culture, history and community. The Hague: Kluwer, 2000.

KOSKENNIEMI, Martti. Histories of international law: dealing with eurocentrism. Rechtsgeschichte, Frankfurt, v. 19, p. 152-176, 2011.

KOSKENNIEMI, Martti. The gentle civilizer of nations: the rise and fall of international law 1870-1960. Cambridge: Cambridge University Press, 2001.

KOSKENNIEMI, Martti. Why history of international law today? Rechtsgeschichte, Frankfurt, v. 4, p. 61-66, 2004.

LACAPRA, Dominick. Articulating intellectual history, cultural history, and critical theory. In: LACAPRA, Dominick. History and its limits: human, animal, violence. Ithaca: Cornell University Press, 2009. p. 13-36.

LACAPRA, Dominick. Introduction. In: LACAPRA, Dominick. History and its limits: human, animal, violence. Ithaca: Cornell University Press, 2009.

LESAFFER, Randall. International law and its histo- 
ry: the story of an unrequited love. In: CRAVEN, Matthew; FITZMAURICE, Malgosia; VOGIATZI, Maria (Ed.). Time, history and international law. Leiden: Martinus Nijhoff, 2007. p. 27-42.

MACEDO, Paulo Emílio Vauthier Borges de. O mito de Francisco de Vitória: defensor dos índios ou patriota espanhol? Revista de Direito Internacional, Brasília, v. 9. n. 1, p. 1-13, 2012.

MATE, Reyes. Medianoche en la historia: comentarios a las tesis de Walter Benjamin 'sobre el concepto de historia'. Madrid: Trotta, 2006.

ONUMA, Yasuaki. A transcivilizational perspective on international law: questioning prevalent cognitive frameworks in the emerging multi-polar and multi-civilizational world of the twenty-first century. Recueil des Cours de l'Académie de Droit International de la Haye, La Haye, v. 342, p. 77-410, 2009.

ORFORD, Anne. The past as law or history? the relevance of imperialism for modern international law. In: TOUFAYAN, Mark; TOURME-JOUANNET, Emmanuelle; RUIZ FABRI, Hélène (Ed.). Droit international et nowvelle approches sur le Tiers-Monde: entre repetition et renouveau. Paris: Societé de Législation Comparée, 2013. p. 97-117.

PASTOR RIDRUEJO, José António. Curso de derecho internacional público y organizaciones internacionales. 6. ed. Madrid: Tecnos, 1996.
POCOCK, J. G. A. Law, sovereignty and history in a divided culture: the case of New Zealand and the Treaty of Waitangi. MoGill Law Journal, Montreal, v. 43, n. 1, p. 481-506, 1998.

REDSLOB, Robert. Histoire des grands principes du droit des gens. Paris: Librairie Arthur Rousseau, 1923.

REMIRO BROTÓNS, António et al. Derecho internacional: curso general. Valencia: Tirant lo Blanch, 2010.

SCOTT, Joan W. History-writing as critique. In: JENKINS, Keith; MORGAN, Sue; MUNSLOW, Alun (Ed.). Manifestos for history. London: Routledge, 2007. p. 19-38.

SOUTHGATE, Beverley. A pair of white gloves: historians and ethics. Rethinking History, London, v. 10, n. 1, p. 49-61, 2006.

SOUTHGATE, Beverley. What is history for? London: Routledge, 2005.

VERDROSS, Alfred. Derecho internacional público. 4. ed. Madrid: Aguilar, 1961.

WEIL, Prosper. Towards relative normativity in international law? American Journal of International Law, Washington, v. 77, n. 3, p. 413-442, 1983.

WINDSCHUTTLE, Keith. The killing of history: how literary critics and social theorists are murdering our past. San Francisco: Encounter Books, 2000. 
Para publicar na Revista de Direito Internacional, acesse o endereço eletrônico www.rdi.uniceub.br ou www.brazilianjournal.org.

Observe as normas de publicação, para facilitar e agilizar o trabalho de edição. 